\title{
Treatment approach in our hypertriglyceridemia induced acute pancreatitis patients
}

\author{
Hipertrigliseridemi ilişkili akut pankreatitli hastalarda tedavi yaklışımımız
}

\author{
Utku Erdem Soyaltın, Tuba Demirci Yıldırım, Emin Taşkıran, Andaç Develi, \\ Ferhat Ekinci, Bilgin Demir, Harun Akar \\ Department of Internal Medicine, Tepecik Training and Research Hospital, İzmir, Turkey
}

ABSTRACT

Objectives: We aimed to research the superiority of insulin infusion and triglyceride apheresis for the treatment of hypertriglyceridemia-induced acute pancreatitis (HIAP).

Patients and methods: In this retrospective, single-center cohort study, demographic data, clinical and biochemical parameters of HIAP were retrieved from the medical record database. The clinical data of 12 patients with HIAP were retrospectively analyzed.

Results: The indication and timing of intervention and which treatment modality in HIAP is most efficacious remains unclear. We want to highlight our experience that seems to be equal therapeutic potential of both options.

Conclusion: In treatment of HIAP, comorbidities should be taken into consideration and treatment should be personalized. More studies are needed to help define the best treatment option for HIAP.

Keywords: Acute pancreatitis; Balthazar score; hypertriglyceridemia; triglyceride apheresis.

$\ddot{O Z Z}$

Amaç: Çalışmamızda hipertrigliseridemi ilişkili akut pankreatit (HIAP) tedavisinde insülin infüzyonu ve trigliserid aferezinin, birbirine üstünlüğünü araştırmayı amaçladık.

Hastalar ve yöntemler: Retrospektif, tek merkezli, kohort olan bu çalışmada, HïAP'nin klinik ve biyokimyasal parametreleri tıbbi kayıt veri bankasından elde edildi. On iki HİAP'li hastanın klinik verileri retrospektif olarak incelendi.

Bulgular: HİAP'de tedavi endikasyonu, zamanlaması ve hangi tedavi yönteminin en etkili olduğu halen net değildir. Her iki tedavi seçeneğinin eşit iyileştirici potansiyeli olduğuna dair deneyimlerimizi vurgulamak istiyoruz.

Sonuç: HIAP tedavisinde komorbit hastalıklar dikkate alınmalı ve tedavi bireyselleştirilmelidir. HİAP için en iyi tedavi seçeneğini tanımlamak için daha fazla çalışmaya intiyaç duyulmaktadır.

Anahtar sözcükler: Akut pankreatit; Baltazar skoru; hipertriglisidemi; trigliserid aferezi.

Hypertriglyceridemia (HTG) causes acute pancreatitis (AP) in $1.3-3.8 \%$ of the patients. ${ }^{[1]}$ Hypertriglyceridemia is the most common etiology of AP next to alcohol and gallstone-induced disease. $^{[1,2]}$ Moreover, HTG was listed as causative in $56 \%$ of cases with gestational pancreatitis. ${ }^{[3]}$ It is generally believed that the risk of acute pancreatitis increases in patients with severe HTG [a triglyceride (TG) level of more than $1000 \mathrm{mg} / \mathrm{dL}$. Although the mechanism of hypertriglyceridemia-induced acute pancreatitis (HIAP) is not clear, hydrolysis of TGs in and around the pancreas by pancreatic lipase seeping out of the acinar cells leads to accumulation of free fatty acids (FFAs) in high concentrations. Free fatty acids are toxic and destroys acinar cells and capillary endothelium. Moreover, an increased concentration of chylomicrons causes capillary plugging, ischemia, and acidosis. Free fatty acid in acidosis activate trypsinogen and initiate 
acute edematous and necrotizing pancreatitis. Interestingly, beyond the apparent significance of a TG threshold level to initiate AP, the severity of HIAP does not seem to correlate directly with TG level. Although the patient is undergoing treatment, the clinician should investigate the etiology of the HTG, such as reviewing patient medications, medical history, or obtaining a detailed family history looking for familial hyperlipidemias. Frederickson classification I, IV, and $\mathrm{V}$ dyslipidemias are associated with severe HTG and predisposition for AP. ${ }^{[4]}$ Type IV, known as familial HTG or familial combined hyperlipidemia, is autosomal dominant and presents in adulthood. Hypertriglyceridemiainduced acute pancreatitis occurs often in untreated or uncontrolled diabetes..$^{[1,2,5]}$ In type I diabetes the absence of insulin reduces the ability of lipoprotein lipase to reduce TG subversion into fatty acids, resulting in elevated TG levels ${ }^{[6]}$ In type II diabetes, insulin resistance leads to enhanced production and reduced clearance of TG. ${ }^{[7]}$ Diabetic ketoacidosis may pose a separate risk for HTG. The role of alcohol in HTG is unclear but may be attributed to alcohol competing with free fatty acids for oxidation, leaving more free fatty acids available for TG synthesis. ${ }^{[5]}$ In addition, hypothyroidism, medications (i.e estrogen, protease inhibitors, olanzapine, mirtazapine, isotretinoin) are known to raise the serum TG level.

Multiple treatment modalities have been suggested in the management of HIAP. Hypertriglyceridemia-induced acute pancreatitis has been treated with infusions of insulin and/or heparin to enhance lipoprotein lipase activity, and apheresis to remove TG. To date, no randomized trials have compared the efficacy of insulin and heparin to apheresis for the treatment of HIAP. There are no definitive guidelines for severe HIAP therapy. However, maintenance of TG levels below $500 \mathrm{mg} / \mathrm{dL}$ has been seen in multiple case series to expedite clinical improvement. ${ }^{[2]}$

Since patients with HIAP need therapeutic strategies aimed at rapidly reducing serum TG levels, we have retrospectively reviewed the cases hospitalized with the diagnosis of HIAP that were successfully treated by either insulin and TG apheresis.

\section{PATIENTS AND METHODS}

This retrospective study comprised of 12 patients (8 males, 4 females; mean 41.58 years; range 33 to 54 years) admitted to İzmir Tepecik Training and Research Hospital with hyperlipidemic pancreatitis and who were treated besides the usual treatment of AP with either insulin infusion and TG apheresis between January $1^{\text {st }} 2012$ and December $31^{\text {st }}$ 2014. In addition to serum TG concentrations $>1,000 \mathrm{mg} / \mathrm{dL}$, at the time of admission to the emergency department the patients were enrolled in this retrospective study who fulfilled clinical (suggestive abdominal pain), analytical (elevated serum amylase and lipase or urine amylase three times the upper limit of normal) and radiological (abdominal CT) criteria of acute pancreatitis. We gathered information on demographic data, a family history of dyslipidemia, and a personal history of dyslipidemia, medical treatment of dyslipidemia, diabetes, hypertension, previous episodes of pancreatitis, alcohol consumption, and smoking, as well as biochemical and hematological data. The patients were classified for severity according to their Ranson criteria and Balthazar score. Insulin was administered intravenously in continuous infusion of $0.1-0.3 \mathrm{U} / \mathrm{kg}$ per hour with titration as required or we used a Liposorber ${ }^{\circledR}$ D DL-75 column with a Kaneka MA-03 machine (Kaneka Corporation, Osaka, Japan). DL-75 is a whole blood adsorption filter and part of the Liposorber ${ }^{\circledR} \mathrm{D}$ system for TG apheresis. The patients' medical records were retrospectively evaluated in this study.

\section{RESULTS}

Since, 12 patients were eligible for inclusion, the clinical (Balthazar score, Ranson criteria), demographical data, serum TG levels and history of various comorbidities of 12 patients with HIAP were summarized in Table 1 . A retrospective analysis of 12 cases of HIAP in the Department of Internal Medicine in our hospital during January $1^{\text {st }} 2012$ and December $31^{\text {st }} 2014$ was performed; the clinical treatment features were analyzed in terms of treatment options, length of stay in hospital and Ranson score. Non of the patients enrolled in the study had a past medical history of alcohol and familial hyperlipidemia. The serum TG levels ranged from $1,035 \mathrm{mg} / \mathrm{dL}$ to $2,381 \mathrm{mg} / \mathrm{dL}$, with a mean of $1,701.4 \mathrm{mg} / \mathrm{dL}$ 
Table 1. The clinical, demographic data and serum triglyceride levels before and after the treatment

\begin{tabular}{|c|c|c|c|c|c|c|c|c|}
\hline Patient & Age/gender & $\begin{array}{l}\text { Hospitalization } \\
\text { time (days) }\end{array}$ & Comorbidite & $\begin{array}{l}\text { Baltazar } \\
\text { score }\end{array}$ & $\begin{array}{l}\text { Ranson } \\
\text { criteria }\end{array}$ & $\begin{array}{l}\text { Treatment } \\
\text { approach }\end{array}$ & $\begin{array}{c}\text { Pre-treatment } \\
\text { triglyceride levels } \\
(\mathrm{mg} / \mathrm{dL})\end{array}$ & $\begin{array}{c}\text { Triglyceride levels } \\
\text { at discharge } \\
(\mathrm{mg} / \mathrm{dL})\end{array}$ \\
\hline 1 & $45 / F$ & 6 & HTN & A & 1 & A & 1857 & 270 \\
\hline 2 & $34 / \mathrm{M}$ & 6 & DM, DL & A & 1 & I & 1617 & 387 \\
\hline 3 & $40 / \mathrm{M}$ & 8 & HTN & D & 1 & A & 1035 & 224 \\
\hline 4 & $40 / \mathrm{M}$ & 5 & DM, DL & C & 2 & I & 1057 & 299 \\
\hline 5 & $50 / \mathrm{M}$ & 7 & HTN, DL & $\mathrm{D}$ & 2 & A & 2381 & 380 \\
\hline 6 & $42 / \mathrm{M}$ & 6 & $\mathrm{DM}, \mathrm{DL}$ & C & 2 & I & 1974 & 234 \\
\hline 7 & $37 / \mathrm{M}$ & 12 & DL & $\mathrm{D}$ & 1 & A & 1717 & 338 \\
\hline 8 & $50 / \mathrm{F}$ & 10 & HTN & C & 2 & A & 1467 & 248 \\
\hline 9 & $33 / \mathrm{M}$ & 5 & $\mathrm{DM}$ & $\mathrm{C}$ & 1 & I & 1608 & 187 \\
\hline 10 & $39 / F$ & 11 & HTN & $\mathrm{D}$ & 2 & A & 2285 & 356 \\
\hline 11 & $35 / \mathrm{M}$ & 12 & $\mathrm{DM}, \mathrm{DL}$ & $\mathrm{D}$ & 1 & I & 1635 & 329 \\
\hline 12 & $54 / \mathrm{F}$ & 6 & HTN, DM & $\mathrm{D}$ & 2 & I & 1784 & 192 \\
\hline
\end{tabular}

HTN: Hypertension; DM: Diabetes mellitus; DL: Dyslipidemia; A: Apheresis; I: Insulin.

(Table 1). Mean hospital stay of the patients and TG levels at the discharge were evaluated. Mean hospital stay of the patients was 7.8 days (ranged from 5 days to 12 days). Interpretation of the results showed insulin was administered in diabetic patients $(n=6)$ and TG apheresis was performed in the other patients $(n=6)$. The types of treatment performed and TG levels at the discharge were summarized in Table 1 . We had six patients with a Baltazar grade 4 score. Among these six patients with a Baltazar grade 4 (D) score, four of them were in apheresis, two of them were in insulin infusion group. Triglyceride reduction ratios were evaluated. Mean TG reduction ratios were $84.55 \%$ and $81.78 \%$ in the insulin infusion and apheresis group, respectively ( $p>0.05$ ). Triglyceride reduction ratios were also evaluated in terms of Ranson criteria. Triglyceride reduction ratios were $81.38 \%$ and $83.43 \%$ in patients with Ranson score 1 and in patients with Ranson score 2, respectively. Mean TG reduction ratios were $82.21 \%$ and $82.60 \%$ in the insulin infusion and apheresis group, respectively ( $>0.05$ ) without considering Balthazar score, Ranson criteria. There was no statistical difference between the two groups (insulin and apheresis) in terms of mean hospital stay, short-term mortality and morbidity.

\section{DISCUSSION}

Hypertriglyceridemia-induced acute pancreatitis often presents in uncontrolled diabetics, ${ }^{[1,2]}$ insulin can both enhance lipoprotein lipase activity and manage hyperglycemia. ${ }^{[8]}$ However, insulin is not limited to HIAP in diabetics, and has successfully treated non-diabetics with HIAP. ${ }^{[9,10]}$ Intravenous insulin may be more effective than subcutaneous insulin in severe cases of HIAP given the potential limitations of absorption with the subcutaneous route. Intravenous insulin may be given as a continuous infusion starting with $0.1-0.3 \mathrm{U} / \mathrm{kg}$ per hour with titration as required.

Apheresis for HTG treatment was first reported in 1978. ${ }^{[11]}$ Since then many case reports and series have utilized apheresis for HTG. ${ }^{[12,13]}$ Apheresis may also confer an additional benefit by allowing removal of proteases associated with AP or hypothetically an infusion of protease inhibitors. ${ }^{[14]}$ However, Leese et al. ${ }^{[15]}$ infused fresh frozen plasma into 72 patients with AP in an attempt to replenish proteins in the anti-protease system, but found no improvement in clinical outcome.

In a study by Chen et al., ${ }^{[16]}$ patients with HIAP were studied before and after apheresis was available at their hospital. Here, 34 patients were in the first group, when plasmapheresis was not available, and 20 patients were in the second group, when plasmapheresis was available. Comparison of the two groups showed no statistical difference in mortality or complications, leading to the conclusion that apheresis had little benefit on overall mortality and morbidity. Even when patients with severe HIAP (Ranson $\geq 3$ ) were analyzed separately, apheresis did not improve overall rates of mortality or complications. The lack of benefit was attributed to a delay in the initiation of apheresis in this study. Establishment of indications for apheresis and guidelines for its 


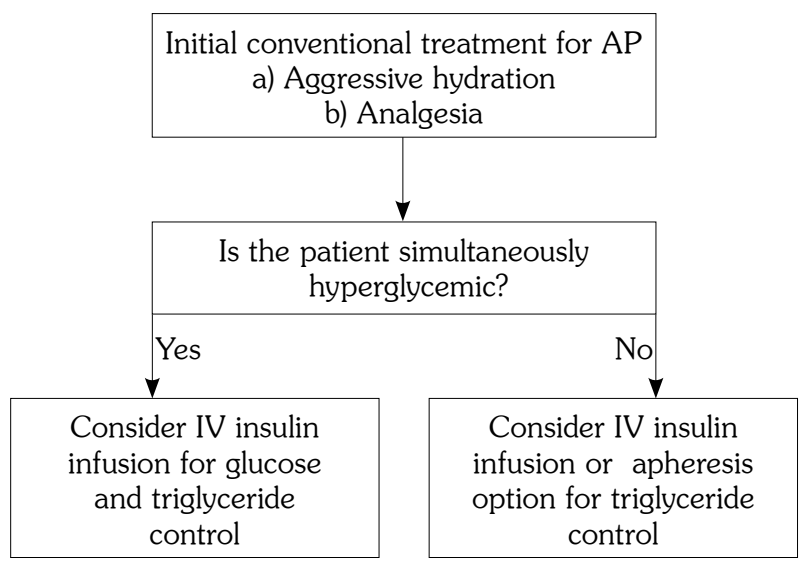

Figure 1. Proposed approach to hypertriglyceridemic pancreatitis. AP: Acute pancreatitis.

timing will require further investigation. However, early initiation of treatment with HIAP is likely to be beneficial. Several considerations regarding technical factors for apheresis have been initially addressed. According to a committee of the American Society of Apheresis in 2013, TG apheresis is recommended to treat patients with HIAP as Category III indication. No official recommendations exist regarding HTGP management, and evidence based data is lacking. Patients with HIAP need to be hospitalized and treated with insulin infusion or therapeutic apheresis (Figure 1). Our series provides data on 12 consecutive patients who underwent either TG apheresis and insulin infusion due to acute pancreatitis and severe HTG. Other authors did not find a clear association between the use of TG apheresis and either improvement length of stay in overall hospital length of stay or in the prevention of complications secondary to pancreatitis. ${ }^{[17]}$ Furthermore, differences in morbidity and mortality were not found between patients with HIAP treated with plasma exchange and conventionally like our study. ${ }^{[18]}$

\section{Conclusion}

Hypertriglyceridemic acute pancreatitis can be treated with TG apheresis, with very few adverse effects. As the indication for TG apheresis is not supported by randomized clinical trials, multicenter studies are needed in order to provide a sufficient sample size and in which the patients are randomized to receive either conventional treatment or TG apheresis. This will enable determination of the benefits in terms of short and long-term mortality and morbidity derived from the procedure.

\section{Declaration of conflicting interests}

The authors declared no conflicts of interest with respect to the authorship and/or publication of this article.

\section{Funding}

The authors received no financial support for the research and/or authorship of this article.

\section{REFERENCES}

1. Fortson MR, Freedman SN, Webster PD. Clinical assessment of hyperlipidemic pancreatitis. Am J Gastroenterol 1995;90:2134-9.

2. Toskes PP. Hyperlipidemic pancreatitis. Gastroenterol Clin North Am 1990;19:783-91.

3. Chang CC, Hsieh YY, Tsai HD, Yang TC, Yeh LS, Hsu TY. Acute pancreatitis in pregnancy. Zhonghua Yi Xue Za Zhi (Taipei) 1998;61:85-92.

4. Fredrickson DS. An international classification of hyperlipidemias and hyperlipoproteinemias. Ann Intern Med 1971;75:471-2.

5. Yadav D, Pitchumoni CS. Issues in hyperlipidemic pancreatitis. J Clin Gastroenterol 2003;36:54-62.

6. Havel RJ. Approach to the patient with hyperlipidemia. Med Clin North Am 1982;66:319-33.

7. Rivellese AA, De Natale C, Di Marino L, Patti L, Iovine C, Coppola S, et al. Exogenous and endogenous postprandial lipid abnormalities in type 2 diabetic patients with optimal blood glucose control and optimal fasting triglyceride levels. J Clin Endocrinol Metab 2004;89:2153-9.

8. Alagözlü H, Cindoruk M, Karakan T, Unal S. Heparin and insulin in the treatment of hypertriglyceridemiainduced severe acute pancreatitis. Dig Dis Sci 2006;51:931-3.

9. Jabbar MA, Zuhri-Yafi MI, Larrea J. Insulin therapy for a non-diabetic patient with severe hypertriglyceridemia. J Am Coll Nutr 1998;17:458-61.

10. Mikhail N, Trivedi K, Page C, Wali S, Cope D. Treatment of severe hypertriglyceridemia in nondiabetic patients with insulin. Am J Emerg Med 2005;23:415-7.

11. Betteridge DJ, Bakowski M, Taylor KG, Reckless JP, de Silva SR, Galton DJ. Treatment of severe diabetic hypertriglyceridaemia by plasma exchange. Lancet 1978;1:1368.

12. Bae JH, Baek SH, Choi HS, Cho KR, Lee HL, Lee OY, et al. Acute pancreatitis due to hypertriglyceridemia: report of 2 cases. Korean J Gastroenterol 2005;46:475-80.

13. Yeh JH, Chen JH, Chiu HC. Plasmapheresis for hyperlipidemic pancreatitis. J Clin Apher 2003;18:181-5. 
14. Iskandar SB, Olive KE. Plasmapheresis as an adjuvant therapy for hypertriglyceridemia-induced pancreatitis. Am J Med Sci 2004;328:290-4.

15. Leese T, Holliday M, Watkins M, Thomas WM, Neoptolemos JP, Hall C, et al. A multicentre controlled clinical trial of high-volume fresh frozen plasma therapy in prognostically severe acute pancreatitis. Ann R Coll Surg Engl 1991;73:207-14.

16. Chen JH, Yeh JH, Lai HW, Liao CS. Therapeutic plasma exchange in patients with hyperlipidemic pancreatitis. World J Gastroenterol 2004;10:2272-4.

17. SyedH,BilusicM,RhondlaC, TavariaA.Plasmapheresis in the treatment of hypertriglyceridemia-induced pancreatitis: A community hospital's experience. J Clin Apher 2010;25:229-34.

18. Chen JH, Yeh JH, Lai HW, Liao CS. Therapeutic plasma exchange in patients with hyperlipidemic pancreatitis. World J Gastroenterol 2004;10:2272-4. 